\title{
The Effect of Biscuits Made From Pumpkin Seeds Flour on Serum Zinc Levels and Weight in Malnutrition Wistar Rats
}

\author{
Aminuddin Syam ${ }^{1 *}$, Fitrah Khaerani Burhan ${ }^{1}$, Veni Hadju${ }^{1}$, C. Citrakesumasari ${ }^{1}$, Andi Muhammad Akhmar ${ }^{2}$ \\ ${ }^{1}$ Department of Nutrition Science, Faculty of Public Health, Hasanuddin University, Makassar, Indonesia; ${ }^{2}$ Department of Local \\ Literature, Faculty of Cultural Science, Hasanuddin University, Makassar, Indonesia
}

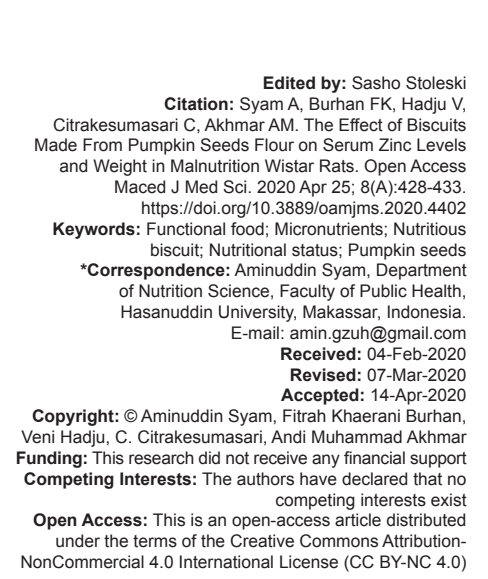

Introduction

The prevalence of global malnutrition in children aged 6-12 years shows the average prevalence of stunting between $20 \%$ and $30 \%$ in all regions except Latin America. The average prevalence of underweight is $17 \%$, wasting $35 \%$; overweight $16 \%$ and $8 \%$ are obese [1]. In Indonesia, based on data from the Basic Health Research (Riskesdas) 2018, the prevalence of wasting, overweight/ obesity, and stunting was relatively high $(9.2 \%, 20.0 \%$, and $23.6 \%$, respectively) [2].

Malnutrition can be an energy deficit (protein energy malnutrition-PEM) or micronutrient deficiency [3]. Insulin like growth factor 1 is a growth hormone mediator that acts as a growth promoting factor in the growth process. Decrease in IGF-1 concentration is caused not only by a lack of protein energy but also zinc deficiency [4]. Serum zinc levels are found to be low in children of protein energy malnutrition globally. In PEM children often zinc deficiency occur which can cause decreased appetite, growth failure, skin injury, diarrhea, healing old wounds and lack of immune response, and inhibit the recovery stage in PEM children. Zinc supplementation during the rehabilitation phase of malnutrition has been linked to rapid weight gain [5]. The previous studies in severely malnourished children demonstrated an increased weight after administering zinc supplementation for two weeks [6].

Mineral zinc $(Z n)$ is one of the important nutrients needed by the body in maintaining health. This mineral plays a role in a variety of enzyme activities, cell growth, and differentiation, and plays an important role in optimizing the function of the immune system [7]. Based on the IZiNCG technique, the global prevalence of zinc deficiency is estimated at $31 \%$, starting at $4-73 \%$ in the sub regional. In developing countries, zinc deficiency is common in infants and children who cause growth retardation, along with a high incidence of severe infectious diseases such as diarrhea, pneumonia, and malaria [8].

One strategy for increasing the production and/or intake of zinc-rich foods in populations at risk of zinc deficiency is by modifying/diversifying the diet [9]. Zinc source foods such as meat and liver tend to be expensive and have low consumption levels. A new innovation is needed by utilizing other local food ingredients that contain high amounts of zinc for 
supplementation so that children's zinc needs can be met [10], [11].

At present, pumpkin seeds have received considerable attention, because they contain beneficial nutrients, such as protein, fiber, minerals, fatty acids, and phytosterols. Based on the USDA National nutrition database, zinc content of $100 \mathrm{~g}$ of pumpkin seeds is $7.81 \mathrm{mg}$. Several studies have developed the addition of pumpkin seed flour as an economical nutritious food with a very acceptable taste. Sensory characteristics in formulas made from pumpkin seed flour mixed with bread, biscuits, and cake products are highly accepted [12], [13]. Results of the analysis on $100 \mathrm{~g}$ of pumpkin seed flour obtained $6.8 \mathrm{mg}$ zinc content [14]. The use of pumpkin seed flour in additional food porridge significantly increases zinc content without reducing the nutritional value and quality of the local complementary food [15].

The previous study has been formulated biscuits made from pumpkin seeds with organoleptic test results obtained formula I with a comparison of pumpkin seed flour and wheat flour (20\%: $80 \%$ ). Based on the analysis of nutrient content in $100 \mathrm{~g}$ of biscuits made from pumpkin seed flour produces about 534.7 $\mathrm{kcal}$ of total calories. The composition of macronutrients is $48.16 \mathrm{~g}$ of carbohydrates, $33.05 \mathrm{~g}$ of fat, and $11.20 \mathrm{~g}$ of protein. Content of micronutrients is around $8.22 \mathrm{mg}$ of Vitamin A, $0.27 \mathrm{mg}$ of Vitamin C, $6.08 \mathrm{mg}$ of calcium, $36.77 \mathrm{mg}$ of potassium, $46.23 \mathrm{mg}$ of chlorine, $0.5 \mathrm{mg}$ of molybdenum, and zinc content of $1.52 \mathrm{mg}$ [16].

Considerations affecting decisions regarding the method of supplying zinc supplementation are solubility, bioavailability, taste, side effects, and frequency of doses administered [9]. Before it is applied to humans, a series of experiments using animal models need to be carried out. It has been reported that zinc is very important for mouse growth, where the mouse growth is very low in the ration without additional zinc given [17]. Wistar rats are one of the most widely used experimental animals as models in biomedical research. Serum or plasma zinc is the best biomarker available to assess the risk of zinc deficiency [18].

This study aims to determine the effect of giving biscuits made from pumpkin seed flour to serum zinc levels and body weight in malnutrition Wistar rats.

\section{Materials and Methods}

\section{Location and research design}

This research was conducted in June 2019July 2019. The location of biscuits is substituted for pumpkin seeds production at the Faculty of Public Health - Culinary Laboratory of Hasanuddin University.
The process of research and weighing in experimental animals is carried out in the Laboratory Biopharmacy Laboratory of the Faculty of Pharmacy, Hasanuddin University. Examination of serum zinc levels at the Makassar Health Laboratory Center. Measurement of serum zinc levels using the atomic absorption spectrophotometry method, body weight measurements using Henherr digital scales $(\mathrm{g})$. This research is a true experimental with a pre-post-test with control group design.

\section{Population and samples}

This study used experimental animals of male white rats Wistar strain (Rattus Norvegicus strain Wistar) aged 8 weeks induced malnutrition by fasting for 3 days by providing drinking water ad libitum. A total of 28 rats were divided into four groups, control (C) group, P1 group receiving a zinc dose of 0.027 $\mathrm{mg} / 1.8 \mathrm{~g}$ of biscuits, P2 group receiving a dose of zinc $0.054 \mathrm{mg} / 3.6 \mathrm{~g}$ of biscuits, and P3 group receiving a zinc dose of $0.081 \mathrm{mg} / 5.4 \mathrm{~g}$ of biscuits/BW/day. The intervention has been given for 14 days with a standard feed, 2 times per day. Determination of multilevel zinc dose based on the results of human conversion to mice (0.018) from biscuits made from pumpkin seed flour with zinc content of $1.5 \mathrm{mg}, 3 \mathrm{mg}$, and $4.5 \mathrm{mg}$ or $30 \%$, $60 \%$, and $90 \%$ of RDA for child, respectively.

Each group used two cages, meaning that one cage was filled with four rats and another cage was filled with three rats. In the end of the study, the rats were not terminated, but donated to the biopharmacy laboratory for further investigations. This study received ethics approval from the Health Research Ethics Committee, School of Public Health, Hasanuddin University (No. 15071945017).

\section{Data analysis}

Normality and homogeneity analysis were performed using SPSS v.21 (IBM Corp). Paired t-test and one-way ANOVA test were used to see differences in serum zinc levels and body weight between intervention groups and post hoc test analysis with the least significant difference (LSD) method to calculate the values of different groups. Interpretation of test results on groups with a significance value of $p<0.05$ indicates there is a significant difference.

\section{Results}

Table 1 shows an increase in serum zinc levels in P2 group (0.054 mg dose) with mean zinc levels before intervention at $4.74 \mathrm{mg} / \mathrm{L}$ and after intervention increasing to $5.13 \mathrm{mg} / \mathrm{L}$ but not statistically significant. 
After performing paired t-test analysis, we found no significant differences of zinc serum change in all intervention and control groups $(p>0.05)$. Based on the results of the one-way ANOVA test, the mean zinc levels between groups after intervention showed no significant difference where the $p=0.481>0.05$.

Table 1: Analysis of zinc levels in Wistar rats before and after the intervention

\begin{tabular}{|c|c|c|c|c|c|c|}
\hline \multirow[t]{3}{*}{ Group } & \multirow[t]{3}{*}{$\mathrm{n}$} & \multicolumn{2}{|c|}{ Serum zinc $(\mathrm{mg} / \mathrm{L})$} & \multirow[t]{3}{*}{$\Delta$ Mean } & \multirow{3}{*}{$\begin{array}{l}\text { Change } \\
\%\end{array}$} & \multirow[t]{3}{*}{$\mathrm{p}^{*}$} \\
\hline & & Pre-test & Post-test & & & \\
\hline & & Mean \pm SD & Mean \pm SD & & & \\
\hline C (Control) & 7 & $8.06 \pm 5.53$ & $4.72 \pm 2.14$ & -3.33 & 41.31 & 0.085 \\
\hline $\mathrm{P} 1$ (Dose $0.027 \mathrm{mg}$ ) & 6 & $10.25 \pm 9.18$ & $4.73 \pm 1.18$ & -5.52 & 53.85 & 0.201 \\
\hline P2 (Dose $0.054 \mathrm{mg}$ ) & 7 & $4.74 \pm 2.46$ & $5.13 \pm 1.97$ & 0.387 & 8.01 & 0.779 \\
\hline P3 (Dose $0.081 \mathrm{mg}$ ) & 6 & $8.19 \pm 3.86$ & $6.43 \pm 3.00$ & -1.76 & 21.48 & 0.510 \\
\hline$p^{\star \star}$ & & 0.391 & 0.481 & & & \\
\hline
\end{tabular}

Table 2 shows that there was an increase in body weight after intervention in each group. Based on paired t-test in each group, there was a significant difference between body weight before and after intervention with $p<0.05$. Greater weight gain occurred in the P1 group (zinc dose $0.027 \mathrm{mg} / 1.8 \mathrm{~g}$ of biscuits) with an increase of $38.85 \%$. Based on the results of the one-way ANOVA test, the average weight between groups after intervention showed a significant difference with $p=0.040<0.05$.

Table 2: Analysis of weight in Wistar rats before and after the intervention

\begin{tabular}{|c|c|c|c|c|c|c|}
\hline \multirow[t]{3}{*}{ Group } & \multirow[t]{3}{*}{$n$} & \multicolumn{2}{|c|}{ Body weight (g) } & \multirow[t]{3}{*}{$\Delta$ Mean } & \multirow[t]{3}{*}{ Change \% } & \multirow[t]{3}{*}{$\mathrm{p}^{*}$} \\
\hline & & Pre-test & Post-test & & & \\
\hline & & Mean \pm SD & Mean \pm SD & & & \\
\hline C (Control) & 7 & $156 \pm 9.75$ & $185 \pm 14.9$ & 29 & 18.58 & 0.000 \\
\hline $\mathrm{P} 1$ (Dose $0.027 \mathrm{mg}$ ) & 6 & $157 \pm 8.88$ & $218 \pm 27.9$ & 61 & 38.85 & 0.002 \\
\hline P2 (Dose $0.054 \mathrm{mg}$ ) & 7 & $160 \pm 17.7$ & $218 \pm 23.0$ & 58 & 36.25 & 0.000 \\
\hline P3 (Dose $0.081 \mathrm{mg}$ ) & 6 & $154 \pm 9.23$ & $206 \pm 21.1$ & 52 & 33.76 & 0.000 \\
\hline$p^{\star \star}$ & & 0.865 & 0.040 & & & \\
\hline
\end{tabular}

Table 3 shows in the post hoc LSD test analysis that there were significant differences in body weight between the control group and the P1 group (dose $0.027 \mathrm{mg}$ ) and P2 (dose $0.054 \mathrm{mg}$ ) with $\mathrm{p}=0.015$ and $p=0.012$, while the other intervention groups did not differ significantly $\mathrm{p}>0.05$.

Table 3: Analysis of weight with post hoc tests LSD

\begin{tabular}{lllll}
\hline Group & $\mathrm{K}$ & $\mathrm{P} 1$ & $\mathrm{P} 2$ & $\mathrm{P} 3$ \\
\hline C (Control) & & 0.015 & 0.012 & 0.105 \\
P1 (Dose 0.027 mg) & 0.015 & & 0.998 & 0.369 \\
P2 (Dose 0.054 mg) & 0.012 & 0.998 & & 0.351 \\
P3 (Dose 0.081 mg) & 0.105 & 0.369 & 0.351 & \\
\hline LSD: Least significant difference. & & & &
\end{tabular}

\section{Discussion}

This study showed that there was no effect of giving biscuits made from pumpkin seed flour to serum zinc levels in malnutrition Wistar rats. However, this zinc-sourced biscuit could significantly increase weight of Wistar rats. Serum zinc levels are found to be low in children of protein energy malnutrition globally. Zinc supplementation during the rehabilitation phase of malnutrition has been linked to rapid weight gain [5].
This study found that there were no significant changes of zinc serum due to intervention. However, there was an increase in serum zinc levels in the P2 group who were given a zinc dose of $0.054 \mathrm{mg}$ after the intervention. The zinc dose P2 group had the lowest average initial serum zinc level compared to the other groups. Zinc status is influenced by zinc absorption where low zinc levels will absorb zinc more efficiently than high zinc levels [19]. Zinc absorption is regulated by metallothionein which is synthesized in cells of the digestive wall. If zinc consumption is high, cells in the gastrointestinal wall are partially converted to metallothionein as a deposit and absorption is reduced. This form of storage will be removed with cells of the small intestine wall that is $2-5$ days old [20].

In this study, Wistar was induced by fasting/not being fed for 3 days. Wistar rat that was malnourished before and after intervention showed that rat did not experience zinc deficiency. Deficiency is said if the serum zinc level is $<9.9 \mu \mathrm{mol} / \mathrm{L}$ or $0.65 \mathrm{mg} / \mathrm{L}$ [6]. During fasting, serum zinc concentrations increase due to release by muscles during catabolism; after eating, serum zinc levels decrease progressively due to hormonal changes and absorption of nutrient tissue induced by fuel metabolism [21].

Giving biscuits made from pumpkin seed flour for 14 days did not show significant results, but there was a tendency for an increase in the mean serum zinc level compared to the control group. Similar to Vakili et al. [22] study which showed that there was no significant difference in serum zinc levels for 6 months in primary school children, but there was a positive effect of $10 \mathrm{mg}$ zinc supplementation on serum zinc levels compared with placebo.

Zinc absorption varies greatly and depends not only on the zinc content in food but also on the bioavailability of zinc. In this study, the feed given to the four groups was yellow corn which contained $2 \mathrm{~g}$ of dietary fiber and $0.46 \mathrm{mg} / 100 \mathrm{~g}$ of zinc. In the intervention group, biscuits were added, containing $6.08 \mathrm{mg}$ of calcium and $1.52 \mathrm{mg} / 100 \mathrm{~g}$ of zinc. Pumpkin seed flour used contains high iron which is about $10.43 \mathrm{mg} / 100 \mathrm{~g}$.

Calcium, iron, fiber, and phytate can inhibit zinc absorption [19]. Fitat with zinc cation will form a strong and insoluble complex because the digestive tract is very deficient in phytase enzyme activity, zinc and phytate bonds will be removed through feces. Calcium has a tendency to form complexes with phytate and zinc and will be an insoluble form, causing inhibition of zinc absorption. In addition, intake of micronutrients with valence two such as iron can inhibit zinc absorption. Zinc and iron interactions first occur in the intestine. Interaction type between two is in the form of absorption pathway, iron transport protein on apical side of enterocytes is also known to be a transport protein for zinc, meaning that if the content of 
one element is high it will affect the absorption of other elements [23].

Zinc minerals are included in trace minerals, meaning that relatively little is needed by the body. The body's need for zinc depends on adequate food regulation so that it can provide zinc for the purposes of various metabolic processes in the body. Dose used in this study $1.5 \mathrm{mg} 3 \mathrm{mg}$ and $4.5 \mathrm{mg}$ converted to mice was relatively lower than needed to improve zinc status, which might explain the smaller effect on increasing serum zinc levels than studies using doses that were greater than. The results of Akbar et al. [24] study showed that administration of $2.5 \mathrm{~g}$ of zinc sulfate for 14 days could increase serum zinc levels in rats.

Changes in plasma zinc concentration in the zinc supplementation group were significantly associated with age, with younger children having greater changes in plasma zinc concentration than older children. Giving a dose of $5 \mathrm{mg}$ for 2 weeks at under 2 years significantly zinc plasma levels better than placebo [25]. Giving a dose of $10 \mathrm{mg} /$ day for 3 months in children showed that there was a significant increase in serum zinc in the intervention group [26].

In normal circumstances, grows of rat at 5 g/day. Growth speed depends on the species, sex, age, and balance of nutrients in the ration. Statistical analysis showed that there were significant differences in weight gain in malnutrition Wistar rats before and after the intervention in each group. One of the factors that influence mouse growth is the quality of feed given. Weight gain is mainly caused by the balance of energy and protein and other nutrients contained in the feed [27].

After comparing with the control group, it was found that there was a significant difference in giving biscuits made from pumpkin seed flour for 14 days to the increase in body weight of malnutrition Wistar rats. Based on the results of the post hoc LSD test, there was a significant difference in body weight of malnutrition Wistar rats between the control group and group P1 (dose $0.027 \mathrm{mg}$ ) and P2 (dose $0.054 \mathrm{mg}$ ). Weight gain was greater in the $\mathrm{P} 1$ group with an increase of $38.85 \%$ compared to the P2 group with an increase of $36.28 \%$. Similar to the research of Maukina et al. [28], there was an effect of giving $1.25 \mathrm{mg}$ zinc syrup for 3 months on weight changes in infants with moderate PEM.

Greater weight gain in the $\mathrm{P} 1$ and $\mathrm{P} 2$ intervention groups resulted from biscuit supplemental food and increased appetite. Zinc supplementation stimulates increased consumption of some micronutrients and basal serum zinc and increases plasma alkaline phosphatase levels. An increase in appetite will increase the amount of calorie and protein intake so that with regular consumption the intake will increase compared to the irregular. Excess calories will be stored in the form of fat and protein tissue to increase muscle mass and minerals as enzymes for growth [29], [30]. Research by Candra [31], on the effect of zinc supplementation on growth shows that giving zinc supplementation $10 \mathrm{mg} /$ day for 3 months can improve appetite and nutritional status of weightfor-age in children.

In the process of growth, zinc plays a role in protein synthesis needed for new tissue formation, growth, and normal bone development [32]. Zinc induces neuropeptides in hypothalamus, $\mathrm{GH}$ secretion, endogenous $\mathrm{GH}$ sensitivity, $\mathrm{GH}$ bioactivity, and $\mathrm{GH}$ receptors. Zinc stimulates GHRH which in turn stimulates the pituitary somatotropic area which secretes $\mathrm{GH}$. Zinc is responsible for longitudinal bone growth especially in chondrocyte cells in epiphyses. Thus, zinc affects all mechanisms of cell and bone growth [29].

Zinc has many functions in the body and is very important for all types of animals, because it is involved in the function of various enzymes that have to do with carbohydrate metabolism, energy, degradation, and synthesis of proteins and nucleic acids [33]. Zinc can help the metabolic process and help the work of enzymes in body one of which will increase the function of enzymes in body. If the function of enzymes in body goes well, then intake of food enters the body can be easily absorbed and function optimally in helping growth process [20]. Based on the results of research Alves et al. [34] showed that zinc administration can increase energy, protein intake, carbohydrates, calcium, iron, and zinc.

Pumpkin seed flour biscuits are rich in nutrients, besides containing zinc, the nutrient content of $100 \mathrm{~g}$ of pumpkin seed biscuits made with about $534.7 \mathrm{kcal}$ total calories, $48.16 \mathrm{~g}$ carbohydrates, $33.05 \mathrm{~g}$ fat, and $11,20 \mathrm{~g}$ of protein. In group $\mathrm{P} 1$ received an energy intake of around $9.5 \mathrm{kcal} / 1.8 \mathrm{~g}$ of biscuit $/ 3 \mathrm{ml}$, group P2 around $19 \mathrm{kcal} / 3.6 \mathrm{~g}$ of biscuit/ $6 \mathrm{ml}$, and group P3 around $28.5 \mathrm{kcal} / 5.4 \mathrm{~g}$ of biscuit $/ 9 \mathrm{ml}$. The amount of food intake affects the amount of energy intake which is then stored as fat and ultimately has implications for weight gain from experimental animals. Consumption of a diet that is rich in carbohydrates and fats will cause an increase in the amount of fat deposited in adipose tissue, especially those under the skin and in the abdominal cavity. Any excessive and indirect amount of fat diet and carbohydrate used will be stored in adipose tissue in the form of triglycerides [35].

In this study, the high of dose in the P3 group did not differ significantly from control group; the results were similar to the study of Tsalissavrina et al. [35] that the high-carbohydrate diet group did not differ significantly from the control group. High glucose will stimulate the satiety center located in the ventromedial nucleus in the hypothalamus. In addition, the results of Doherty et al. [36] showed that higher zinc doses were not associated with significant changes in anthropometric measurements, but were associated with significantly greater mortality in children who received high zinc doses $(6.0 \mathrm{mg} / \mathrm{kg})$ compared to 
those who received low-dose zinc supplementation $(1.5 \mathrm{mg} / \mathrm{kg})$. From these findings, therefore, a high dose of zinc supplementation can probably exacerbate deficiency of other minerals by decreasing intestinal absorption. Zinc inhibits copper absorption and copper deficiency occurs in severe PEM.

\section{Conclusions}

The provision of biscuits made from pumpkin seed flour did not affect to increase in serum zinc levels in malnutrition Wistar rats so further research is expected to use different zinc doses. Meanwhile, the provision of biscuits made from pumpkin seed flour influenced the increase in body weight of malnutrition Wistar rats. The highest weight gain was found in the P1 group by giving biscuits by $1.8 \mathrm{~g}$ in malnutrition Wistar rats with an average increase of $38.85 \%$. For further research is worth investigating the possible to see the effect of giving biscuits made from pumpkin seed flour to weight gain in humans.

\section{References}

1. Best C, Neufingerl N, Van Geel L, van den Briel T, Osendarp S. The nutritional status of school-aged children: Why should we care? Food Nutr Bull 2010;31(3):400-17. https://doi. org/10.1177/156482651003100303

\section{PMid:20973461}

2. Kemenkes RI. Laporan Nasional Riskesdas. Jakarta: Badan Penelitian Dan Pengembangan Kesehatan Kementerian Kesehatan Republik Indonesia; 2018.

3. Müller $\mathrm{O}$, Krawinkel M. Malnutrition and health in developing countries. CMAJ 2005;173(3):279-86. PMid: 16076825

4. Kusudaryati DP. Kekurangan Asupan Besi dan Seng Sebagai Faktor Penyebab Stunting Pada Anak. Vol. 10. Profesi (Profesional Islam): Media Publikasi Penelitian; 2014. p. 57-62.

5. Mittal P, Dipti B. Role of zinc in malnutrition. Int J Gastroenterol Hepatol Transplant Nutr 2016;1(4):45-8. https://doi. org/10.26576/profesi.129

6. Brown $\mathrm{KH}$, Hotz $\mathrm{C}$. International zinc nutrition consultative group (IZiNCG) technical document \#1. Assessment of the risk of zinc deficiency in populations and options for its control. Food Nutr Bull 2004;25(1):S99-203. https://doi. org/10.1177/156482650402500220 PMid: 18046856

7. Paik I. Application of chelated minerals in animal production. Asian Austral J Anim Sci 2001;14(SPI):191-8.

8. Rahman MM, Tofail F, Wahed MA, Fuchs GJ, Baqui $A H$, Alvarez JO. Short-term supplementation with zinc and Vitamin A has no significant effect on the growth of undernourished Bangladeshi children. Am J Clin Nutr 2002;75(1):87-91. https:/ doi.org/10.1093/ajen/75.1.87

PMid:11756064
9. Brown KH, Peerson JM, Rivera J, Allen LH. Effect of supplemental zinc on the growth and serum zinc concentrations of prepubertal children: A meta-analysis of randomized controlled trials. Am J Clin Nutr 2002;75(6):1062-71. https://doi. org/10.1093/ajen/75.6.1062

PMid:12036814

10. Kattelmann KK, Ho M, Specker BL. Effect of timing of introduction of complementary foods on iron and zinc status of formula fed infants at 12,24 , and 36 months of age. J Am Diet Assoc 2001;101(4):443-7. https://doi.org/10.1016/ s0002-8223(01)00114-6 PMid:11320951

11. Mulyaningsih TR. The concentration of $\mathrm{Fe}$ and $\mathrm{Zn}$ in agricutural, livestocks, and fishery food products using KO-AANI methods. J. Sains Teknol Nuklir Indones 2009;10(2):71-80. https://doi. org/10.21059/buletinpeternak.v11i1.1800.

12. Dhiman AK, Sharma KD, Attri S. Functional constitutents and processing of pumpkin: A review. J Food Sci Technol 2009;46(5):411-7.

13. Revathy MN, Sabitha N. Development, quality evaluation and popularization of pumpkin seed flour incorporated bakery products. Int J Food Nutr Sci 2013;2(2):40-5.

14. Syam A, Kurniati Y, Zaenal, Puspitasari N, Khaerani F. Nutrient content of pumkin seed (Cucurbita moschata Durch) Makassar City: The $1^{\text {st }}$ International Conference on Nutrition and Public Health, Hotel Claro Makassar; 2019a.

15. Tona Z, Tafese B, Tefera B. Blending germinated maize, pumpkin pulp and its seed improves zinc and Vitamin $A$ without compromising nutritive value and sensory attributes of local complementary food porridge. Food Public Health 2015;5(4):103-7.

16. Syam A, Zaenal YK, Aulia NA, Wati IP, Mansur MA. Development and biochemical analysis of pumpkin seed (Cucurbita moschata Durch) biscuits. Pak J Nutr 2019;18(8):743-6. https://doi. org/10.3923/pjn.2019.743.746

17. Todd WR, Elvehjem CA, Hart EB. Zinc in the nutrition of the rat Am J Physiol Legacy Content 1933;107(1):146-56. https://doi. org/10.1152/ajplegacy.1933.107.1.146

18. De Benoist B, Darnton-Hill I, Davidsson L, Fontaine $O$ Hotz C. Conclusions of the joint WHO/UNICEF/IAEA/ IZiNCG interagency meeting on zinc status indicators. Food Nutr Bull 2007;28(Suppl 3):S480-4. https://doi. org/10.1177/15648265070283s306 PMid: 17988008

19. Roohani N, Hurrell R, Kelishadi R, Schulin R. Zinc and its importance for human health: An integrative review. J Res Med Sci 2013;18(2):144-57.

20. Almatsier S. Prinsip Dasar IImu Gizi. Jakarta: PT Gramedia Pustaka Utama; 2009.

21. King JC, Shames DM, Woodhouse LR. Zinc homeostasis in humans. J Nutr 2000;130(5):1360S-6S. https://doi.org/10.1093/ jn/130.5.1360s PMid:10801944

22. Vakili R, Bakhsh My, Vahedian M, Mahmoudi M, Saeidi M, Vakili S. The effect of zinc supplementation on linear growth and growth factors in primary school children in the suburbs Mashhad, Iran. Int J Pediatr 2015;3(21):1-7.

23. Gropper S, Smith JL, Groff JL. Advanced Nutrition and Human Metabolism. Australia: Thomson; 2005.

24. Akbar B, Niloufar N, Abolfazl M, Lofollah S, Ali KQ, Soheyla V. Evaluation and comparison of zinc absorption level from 2-Alkyle 3-Hydroxy pyranon-zinc complexes and zinc sulfate in rat in vivo. Adv Biomed Res 2013;2(2):1-8. https://doi. org/10.4103/2277-9175.116432

PMid:24223392 
25. Wessells KR, Ouédraogo ZP, Rouamba N, Hess SY, Ouédraogo JB, Brown KH. Short-term zinc supplementation with dispersible tablets or zinc sulfate solution yields similar positive effects on plasma zinc concentration of young children in Burkina Faso: A randomized controlled trial. J Pediatr 2012;160(1):12935. https://doi.org/10.1016/j.jpeds.2011.06.051 PMid:21871635

26. Lopes MM, De Brito NJ, De Medeiros Rocha ÉD, França MC, De Almeida MD, Brandão-Neto J. Nutritional assessment methods for zinc supplementation in prepubertal non zincdeficient children. Food Nutr Res 2015;59(1):29733. https://doi. org/10.3402/fnr.v59.29733

PMid:26507491

27. Cunningham GJ, Klein GB. Text Book of Veterinary Physiology. $4^{\text {th }}$ ed. Philadelphia, PA: Saunders, Elsevier; 2007. p. 328.

28. Maukina R, Wijayanti TR. Pemberian sirup zink berpengaruh terhadap perubahan berat badan pada balita kekurangan energi protein (KEP) Sedang. Care 2018;6(3):267-76. https:// doi.org/10.33366/cr.v6i3.1001

29. de Medeiros Rocha ÉD, de Brito NJ, Dantas MM, de Araújo Silva A, das Graças Almeida M, Brandão-Neto J. Effect of zinc supplementation on GH, IGF1, IGFBP3, OCN, and ALP in nonzinc-deficient children. J Am Coll Nutr 2015;34(4):290-9. https:// doi.org/10.1080/07315724.2014.929511 PMid:25759961

30. Chao HC, Chang YJ, Huang WL. Cut-off serum zinc concentration affecting the appetite, growth, and nutrition status of undernourished children supplemented with zinc. Nutr Clin
Pract 2018;33(5):701-10. https://doi.org/10.1002/ncp.10079 PMid:29603391

31. Candra A. Pengaruh suplementasi seng dan zat besi terhadap berat badan dan tinggi badan balita. J Nutr Health 2017;5(1):3744. https://doi.org/10.14710/jnc.v6i4.18664

32. Agustian L, Sembiring T, Ariani A. Peran Zinkum Terhadap Pertumbuhan Anak. Sari Pediatr 2009;11(4):244-9. https://doi. org/10.14238/sp11.4.2009.244-9

33. Linder MC. Biokimia Nutrisi dan Metabolisme. Jakarta: Universitas Indonesia Press; 1992.

34. Alves CX, Vale SH, Dantas MM, Maia AA, Franca MC, Marchini JS, et al. Positive effects of zinc supplementation on growth, GH, IGF1, and IGFBP3 in eutrophic children. J Pediatr Endocrinol Metab 2012;25(9-10):881-7. https://doi.org/10.1515/ jpem-2012-0120

PMid:23426817

35. Tsalissavrina I, Wahono D, Handayani D. Pengaruh pemberian diet tinggi karbohidrat dibandingkan diet tinggi lemak terhadap kadar trigliserida dan HDL darah pada Rattus novergicus galur wistar. J Kedokteran Brawijaya 2013;22(2):80-9. https://doi. org/10.21776/ub.jkb.2006.022.02.5

36. Doherty CP, Sarkar MA, Shakur MS, Ling SC, Elton RA, Cutting WA. Zinc and rehabilitation from severe proteinenergy malnutrition: Higher-dose regimens are associated with increased mortality. Am J Clin Nutr 1998;68(3):742-8. https:// doi.org/10.1093/ajcn/68.3.742

PMid:9734756 